\title{
第26回 全国地理学専攻学生
}

\section{卒業論文発表大会 記事}

1978 年 3 月19日 (日)

於 東京学芸大学 5 号館

主催 日本地理教育学会

恒例の全国地理学専攻学生卒業論文発表大会は, 本年は19大学37名の発表参加者を迎え, 次のように行なわれた。

第 1 会場 $\quad 09.30 \sim 11.45 \quad 101 \sim 106$

$12.45 \sim 18.30 \quad 107 \sim 119$

第 2 会場 $\quad 09.30 \sim 11.45 \quad 201 \sim 206$

$12.45 \sim 18.30 \quad 207 \sim 218$

また，各発表における座長は次の通りであった。

\begin{tabular}{|c|c|c|c|}
\hline 斉藤＼cjkstart毅（東京学芸大） & $101 \cdot 102$ & 有井玩磨（東京学芸大） & $201 \cdot 202$ \\
\hline 青木栄一（東京学芸大） & $103 \cdot 104 \cdot 112$ & 白井哲之（千葉大） & $203 \cdot 204$ \\
\hline 島義一（駒沢大） & $105 \cdot 106$ & 山下偹二 (東京学芸大) & 206 \\
\hline 村嘉行（東洋大） & $107 \cdot 108 \cdot 109$ & 浅井辰郎 (お茶の水女子大) & \\
\hline 幸雄（横浜市立大） & $110 \cdot 111$ & 中山正民（埼玉大） & $210^{\cdot}$ \\
\hline 清（日本大） & $113 \cdot 114 \cdot 115$ & 松村祝男（千葉商科大） & $212 \cdot$ \\
\hline & $116 \cdot 117$ & 北林吉弘（文教大） & \\
\hline 野征男（ & $118 \cdot 119$ & 斉藤 功 (お茶の水女子大 & \\
\hline
\end{tabular}

\section{卒業論文発表要旨}

\section{1.むつ湾のホタテ養殖—ツリ下げ法の発見と普及——}

黒岡 実（法政大通信教育部）

むつ湾におけるホ夕テガイ漁業は，18年に1度より豊漁がないほど従来から豊凶をくり かえしている。ホ夕テガイは，4月中．下旬にかけての水温が $5 \sim 8{ }^{\circ} \mathrm{C}$ のをき産卵し，最 初海中を浮遊しているが，1 力月経過するころにいろいろな物に付着し，2〜3力月たつ と海底に落下する習性を持っており，この落下する頃にきわめて多くの大量死がでるため， この大量死をなくすことがホ夕テ養殖の最大の課題とされていた。

採苗試験については，北大水産学部の故木下虎一郎氏らにより、昭和 8 年にサロマ湖内 で行なわれており，以後，関係当局，漁民のさまざまな試行錯誤がつづいている。このよ うななかで，青森市奥内の漁民工藤金作氏は，杉の葉に付着した稚貝の落下を防ぐため， 杉の葉を古い網で囲み、かなりの効果をあげた。昭和38年のことである。

これらにヒントを得た工藤豊作氏（金作氏の兄）は，もっと目の細かい網を探し，その 時目にとまったのが，八百屋で使いふるしのタマネギ袋であった。同氏は早速に購入し， 杉の葉をつめて，海中に吊し，自分の試みを不安ながら見守った。しかし: , 幸いにもこの 試みが落下した稚貝を，すべて受けとめ成功した。

このような漁民のきわめて簡単な試みがホ夕テ養殖の技術的発展であり，以後，むつ湾 では全体の稚貝は100万個にも満たなかったものがこのタマネギ袋が普及した昭和 46 年には, 382 億粒，さらに原子力船「むつ」事件があった昭和 49 年には史上最大の 1,000 億粒の大豊作 


\section{となる。}

ところで、むつ湾のホタテガイは昭和 45 年以来, 主産地北海道を追い抜いたものの, 昭 和 50 年より 3 年つづきの大量死に見舞われている。大量死の原因については, 過密養殖, 海況異変, 養殖作業上等, いろいろといわれてはいるものの, はっきりした結論には達し ていない。いずれにしても, 過密養殖が大量死につながっているものと考えられる。密殖 によって起こる酸素不足, エサ不足が同時に貝自体を弱化させ，さらに酸素不足でフンが 分解する際, 硫化物が増加し海底に無酸素状態ができ, 漁場が老朽化する。同じようなこ とがカキで有名な気仙沼でおきている。

この過密養殖については, 限られた漁場での適正な規模の養殖を維持するという漁民自 身の良識ある行動を期待したい。

\section{2. 瀬戸内開発による沿岸漁業の変貌}

浜田泰臣（明治大）

昭和60年代後半の地域開発は都市工業地域の過度集中による弊害を地方分散によって解 消しようとするものであった。それに対し，地方公共団体は公共事業として大規模な工業 用地造成を推し進め, 社会資本を動員して工業資本の受け入れ態勢をとり, 地域経済の高 度化を図ろうとしたのであった。

香川県では, 坂出市沖の備讃瀬戸航路浚渫工事による土砂を利用し, 番の州工業地域を 造成し, 香川県経済の高度化を目論んだ。それはいわば, 香川県の命運をかけた一大事業 であったため，部分的には極めて強権的に推し進めたところもあった。この工業資本の進 出による再編成に, 沿岸漁業がいかに対応し, 変貌したかを考察した。

その結果は番の州工業地域はただ単に社会資本を利用したにすぎず，その機能は水島コ ンビナートをはじめとした瀬戸内既存工業地帯の補完的役割を担うものであった。また, 漁業は高度経済成長のもとで, 沿岸漁業からの労働力間引き政策によって漁業就業人口の 減少, 若年労働力の第 2 - 第 3 次産業への流出は一般化・普遍化していた。しかし, 瀬居 島においては番の州工業地域が造成されて流出パターンに変化が現われた。すなわち，労 働力は需要が距離的に近くにあれば近いほどそこに流出する。しかも工業資本は若年労働 力は必要としても中高齢者は必要としない。それ故, 残された漁業労働力はただ高齢化し てゆくのみである。

漁場を变失，縮小された沿岸漁業民の対応形態は大きく分けて二つの形態に分類できる。 すなわち，一つは脱漁民化の方向をとる形態であり，また一つは小商品生産様式を維持し つつ, 更なる再編成をせまられている形態である。後者は, 不足した労働力を漁具・漁船 の機械化・合理化, 漁業経営の集約化等によって充足させ，また婦人労働力を中心とした 家族労働力の依存度を増大させたのである。とはいえ, 今日の沿岸漁業の労働力状況がそ のまま展開するというほど確固としたものではなく，かつてより漁業労働力は賃労働で一 定期間を経て漁村に還流するという図式があり，日本経済の動向如何では，流出労働力が 失業者群となって漁村に還流してくる可能性は大である。

\section{3. 関東地方における陸山砂利採取地の拡大について}

武藤信一郎 (日本大)

〔目的〕 1 都 3 県 (東京都・埼玉県 ·千葉県・神奈川県) での砂利需要量は, 1968年 から73年のわずか 5 年間に, 約1.5倍増大しており, また全国比においても, 約 $20 \%$ の高率 を占めでいるこのことは，1 都 3 県内での砂利自給率を低下させ，必然的に供給地を他 県へ求めることとなり，また供給構造が河川砂利から陸砂利・山砂利へ転換しつつある状 況の中で, 1 都 3 県およびその周辺諸県では著しい陸山砂利の開発が行なわれたものと考 えられる。本発表は, 関東地方における陸山砂利採取地の拡大について, その実態の一部 
を述べたものである。

〔結果〕東京都・埼玉県を例に，1970年から73における砂利類（河川砂利・陸山砂 利）の県別移入量をみると，まず東京都は，この 3 年間に供給地の大きな変化をみること ができる。すなわち，1970年において，総移入量の $45 \%$ を占めていた神奈川県・埼玉県が， 都市化による法的規制や利権料の高騰などによって，1973年には大きく後退し，代って千 葉県・茨城県・栃木県・静岡県といった周辺県からの移入が著しく伸びている。とくに千 葉県からは，海上輸送による大量輸送によって $53 \%$ を占めるに至った。埼玉県の移入量は， 千葉県から若干増えているが，栃木県からの移入量が 1 位であるのは変わらず，総移入量 の割合では，1970年の $23 \%$ か 1973年には43\%にまで増大している。また，移入量を砂利 種類別にみると, 陸山砂利は河川砂利の減少分を埋め合わせた上に, なおかつ大量の移入 が行なわれている。さらに，陸山砂利の 1 都 3 県への供給地を市町村別に表わすと, 限ら れた地域に集中しているのがわかる。例えば，東京都・埼玉県・千葉県への供給地となる 栃木県南部から茨城県西部へかけての鬼怒川流域と茨城県南部地域であり, 海上輸送によ つて東京都・神奈川県への供給地となる千葉県西部の山砂利採取地域などである。そして経 年的に市町村別の採取量をみても，己れらの地域での採取量が一層増大している。

このように, 1 都 3 県での砂利需要は, 建設ブームによって飛躍的に増大し, 供給地を 他県へ求める結果となったが, 千葉県を除く大部分がトラック輸送であるため, 距離的に も経済的にも，極めて限られた地域に供給地が形成されているのが実態である。

\section{4. 栃木県鹿沼市における鹿沼土営業所の立地}

高橋文子（文教大）

〔序論】現在サツキの培養土として, 広く用いられている鹿沼土は, その大部分が栃 木県鹿沼市で採掘され製品化されている。鹿沼土の原料となる鹿沼軽石層·（K P 層）は, 洪積期の中期に噴出した火山性軽石で, 赤城山中央火口丘の噴出物であり, 分布範囲は赤 城山を中心とした扇形の地域に分布している。

そこで，鹿沼市における鹿沼土採取の営業所の分布を決定する立地要因を地理的立場か ら明らかにすることを研究の目的とし，現地の聞きとりによって得た結果を以下に述べる。

[本論] 鹿沼土は鹿沼市内いたるところで掘られているが, ここに述べる営業所は採 掘現場ではない。鹿沼市におけるその営業所の総数は178戸で, そのうち鹿沼土の採掘を専 業 (年間採掘面積 $40 \mathrm{a}$ 以上, $10 \mathrm{a}$ 当り 6 万袋) とする業者は 15 户で $8 \%$ に当り, 残りの 92 \%の業者は農家やサツキ栽培を兼ねて採掘に従事している。(1)全営業所の97\%が鹿沼市を 北から南に流れる黒川東岸の隆起扇状地に立地している。そのうち北部59戸(33\%), 南部 117 戸 $(67 \%)$ である。(2)どの営業所も幹線道路の近辺に立地している。

立地要因の分析

(1)原料との関係 まずなぜ営業所が黒川東岸隆起扇状地上に立地するのか。園芸用鹿沼 土となる原料は，鹿沼一帯のローム層下に埋もれた鹿沼軽石層であり，大量の K P が得ら れるため産業として成り立つ。それは層の厚さに大きく関係し，さらに商品用としては粒 が比較的そろっていなくてはならない。この 2 条件を共に満たす地域は東西 $7 \mathrm{~km}$, 南北15 $\mathrm{km} の$ 平地が主産地とされ, 北は富岡, 南は磯と黒川の沿岸との間で, 営業所も富岡・仁神 堂・茂呂・苛江に集中し，産出地によってその品質も多少ことなる。

(2)生産コストとの関係 鹿沼土の営業所の $100 \%$ が幹線道路から $0.4 \mathrm{~km}$ 以内に立地してい る。この立地とは採掘現場から営業所までの運搬費を最小ならしめる所に立地しているも のと思われる。生産コスト中の距離と原価中の運搬費の比率を数字化できなかったが，そ れが大であることは地元の業者の多くが認めている。さらに輸送形態がトラック輸送に中 心がおかれ，昭和 $40 〜 45$ 年以降に採掘をはじめた業者の営業所は道路に面している。すな 
わち，その立地が輸送費に支配されるといえよう。

(3)販売との関係 鹿沼土の出荷先は, 県内・関東はもとより, 全国におよぶが, 輸送費 がかさむためその販路は鹿沼を中心に北へ $300 \mathrm{~km}$ 内, 西に $500 \mathrm{~km}$ 内, 半径 $400 \mathrm{~km}$ 以内であまり 遠方へは出荷されていない。主な出荷先としてサツキ栽培の盛んな埼玉, 新潟県などがあ げられ，個人対個人の契約で現地販売されている。

〔結論〕（1鹿沼市には，いたるところに鹿沼土の原料となる鹿沼軽石層の厚層があり， 粒がそろっているため産業として成り立っている。(2)営業所は，主産地といわれる鹿沼市 を中心した東西 $7 \mathrm{~km}$, 南北1 $5 \mathrm{~km}$ の平地に立地し, 条件を備えた地域に集中している。(3) 営業所は, 輸送費との関係や，それをトラック輸送に依存するため，幹線道路の近辺に立 地する。

\section{5. 近世後期日光神領内 2 村の戸口分析一一南小倉と轟の場合}

$$
\text { 柿沼元一（専修大） }
$$

〔研究目的〕近世後期（1780～1860年頃）の農村における家族構成の変化を持高階層 との関連において明らかにする。

〔研究地域〕研究対象としたのは，下野国日光神領南小良村と轟村である。前者は例 幣使街道筋の一村で, 水田と畑が相半ばし, 畑作物では麻の栽培が知られている。後者は 日光街道沿いの一村で，伝統的に畑作中心であり，雑穀として粐・稗・大豆などを作って いた。

〔結果〕 1. 南小倉村の 1 戸当り平均持高は6.52石（文政 4 年-1821）, 轟村は5.88石 (文政 7 年-1824)，でともに巨大地主層などの支配のない平均的村落であった。それぞれ， 上層（持高10石以上), 中層（ 5 石以上，10石未満),下層（ 5 石未満）の農家を含んでいた。

2。南小含村では，享和元年 (1801) に，上層 3 戸 $(8 \%)$, 中層17户 $(46 \%)$, 下層17户 $(46 \%)$ であったが，文久元年（1861）には上層 2 戸 $(5 \%)$ ，中層15户 $(60 \%)$ ，下層 9 户 $(35 \%)$ となり，これを持高の上でみると上層と下層との間の格差が拡大している。轟村 は資料に乏しいが，天保年間（1830４3）以降に階層分化がはっきりしてくる。

3. 1 戸当り家族人数は南小倉村 4.9 人(文政 4 ), 轟村 4.0 人(文政 7 )で, 前者がやや多い。

4. 1 戸当り家族人数を持高階層別にみると, 南小倉村（文政 4 ）では, 上層 3 戸が 3 人， 7 人， 9 人各 1 戸づつ，中層 7 戸が 1 ～ 4 人 5 戸， 5 人 7 戸， 6 〜 10 人 5 戸，下層 17 戸は平均約 2 人となった。

5. 有配偶率 (組数率) 平均は南小倉村（文政 4) $82.1 \%$ ，轟村（文政 7 ） 69.1\%であ った。南小含村の上・中層はとくに有配偶率が高い。両村とも未婚者は下層のうちでも， 持高 1 〜 石の層に多い。

6. 南小倉村では上田が全耕地面積の33\%を占めているのに対し, 轟村では下畑が半分 以上を示した。嘉永 6 年（1853）の荒畑面積では轟村は南小倉村の8倍に達し，土地条件 の上では大差があるほか，南小良村では元禄年間から煙草栽培のような商品作物の導入が 行なわれていた。また木材の伐採・販売も両村で行なわれていたが(嘉永 6 年現在), 南小 倉村では上・中層の参加によってこれが組織的に行なわれていたのに対し，轟村では十分 の組織化がみられなかった。

\section{6. 中世都市清洲の歴史地理学的研究}

梶田典稔 (愛知教育大)

従来の中世都市の研究は，文献史学的な面から構造を中心に解明されてきた。しかし， 囲郭をもった都市の歴史地理学研究は，あまり多くなされていない。

この研究では，囲郭をもつ中世都市である清洲について，文献史学的な面からだけでな 
く, 堀（旧河道をふくむ）, 土居, 町並の復原を行なった。すなわち, 堀の遺構の残存を近 世の各村絵図および地籍図の地割から抽出し，両者を対照しながら現在の位置に比定した。 また，その位置を地形学的調査である表層地質調査を行なうことによって，村絵図にあら われた堀の位置を地籍図におとし，地形学的調査によって，一層たしかな堀の位置をきめ ることができた。

いっぽう土居の遺構については，地籍図および村絵図の残存から復原することができた。 その結果, 堀は清洲の北方, 春日村大字落合の南にその分岐点があり, 三重堀となって 中世城下町清洲をめぐらしていることがわかった。堀の合流点は，南の清洲町大字清洲字 丸之内あたりにあった。

土居は，村絵図，地籍図からみると，その分布は，外堀の内側に隣接して点在していた と思われる。この残存状況から，中世城下町時代に，堀とともにほぼ連続し，城下町を包 囲していたことが明らかとなった。このようにして，中世都市清洲の囲郭式城下町の形態 を復原することができた。

囲郭内における中世城下町時代の町並の復原については, 清洲に残存する地名を記載し た村絵図, 字名調, 駒井日記尾張抄の 3 史 (資) 料を比較した。その結果, 3 史 (資) 料 とも記載された信憑性の高い 9 力町をあげることができた。これらの町は，中世城下町時 代に町並を形成していたことが明らかとなった。

また, 慶長16 (1611) 年の城下町の名古屋移転に伴ない, 清洲越の町は, 名古屋側で信 憑性の高い49力町が確認された。

この49力町と清洲側の 9 力町の対応関係をみると，数的には少ないが，対応関係がみら れ，町並の移転があったことは明らかとなった。しかも，これら清洲越の町々が，名古屋 碁盤割地域の中心部の大部分を占め, 名古屋城下町の経済的発展に寄与したのであった。

なお，囲郭式城下町清洲の規模は，その囲郭の大きさから，東西 $1.6 \mathrm{~km}$, 南北 $2.7 \mathrm{~km}$ とい う大規模な都市であった。

\section{7．結城市の地域性に関する考察一一農業と紬生産を中心として—}

磯前厚子（お茶の水女子大） 結城市は茨城県の西部に位置し, 東は鬼怒川を境に下館市, 西は県境で杤木県小山市と 隣接し, 三連珠型都市の中央にあり，地形的には鬼怒川中流西岸の沖積低地と結城台地の 北部を占める。さて，その結城地方は，古来より 紬産地として有名であり，1 千年余の伝統を維持 してきた。しかも，それは独立して存在してきた のではなく，農業と密接な関連をもって現在に至 っている。そこで, 農業と結城紬は現在いかなる 状況にあり，両者はどのように関連しあい，どん な地域的特色を生み出しているのかを, 地域区分 を通して考察することとした。

研究方法は, 当地域における予備調査, 既存文 献資料の検討を出発点として, 現地での聴き取り, 観察，写真撮影などを中心とした。そして，自分 なりの村域区分を試みた。

地域区分の指標としては，農業集落カード83枚 の詳細なる分析，および本場結城紬織物協同組合 加入者名簿 (1977) の集落別分析から当地域の地

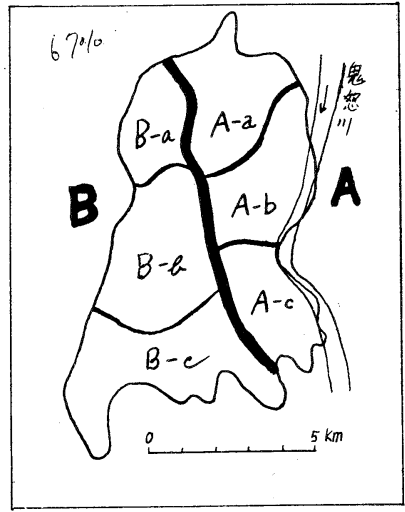

図 I 地域区分図 
域区分に有効と思われるものを選定した。その結果, 組合加入従事者の有無及び従事内容 ・農家率・掃立卵量が重要な指標となることが判明した。また，現地での観察と聴き取り によって，いざり機か高機かという織機の種類も区分の主要な指標となることがわかった。 さらに，地形及び土地利用の点からも考察を加えた。

地域区分図及び各地域の特徵は, 図 I 及び表 Iに示したとおりである。A-b地域は紬生 産の最も盛んな地域で, 紬の副業としての農業になりつつあり, 宮崎集落については, と くに詳細な実態調査を行なった。

表 I 各地域の特徵

\begin{tabular}{|c|c|c|c|c|}
\hline & $\begin{array}{l}\text { 組合 } \\
\text { 加入 }\end{array}$ & 主な紬従事内容 & 織 機 & 農 業・その他 \\
\hline$A-a$ & O & 製織・染色・絣 $<<り$ & いざり機 & 農家率低く，紬が主体 \\
\hline$A-b$ & ○ & 製織・染色・絣 $<く り$ & いざり機 & 農家率高く，紬が主体 \\
\hline$A-c$ & 0 & 製織・絣くくり & 高 機 & 農家率高く，農業が主体 \\
\hline $\mathrm{B}-a$ & $\times$ & 糸つむぎ & な & 通勤兼業多く，養蚛あり \\
\hline $\mathrm{B}-b$ & $\times$ & 系つむぎ & な & 海抜30m 以上，養䖝あり \\
\hline $\mathrm{B}-\mathrm{c}$ & $x$ & 糸つむぎ & な & 海抜30m 以下，養虫ほとんどなし \\
\hline
\end{tabular}

\section{8．鹿沼市における麻工業の立地}

望月節子（文教大）

本地域における製麻工業は，第一に鹿沼や所野の二力所のみに立地し，他に立地してい ない。つぎに，その中でも大部分は鹿沼に集中し，日光への立地はきわめて短期間である。 第 3 に鹿沼の中でも特に集中しているところは，宇都宮街道から大谷街道に沿って，西は 黑川沿岸の下府所から鹿沼駅前を通り，仁神堂に達するきわめて狭い地区に限られている。

これらの分布特色をふまえ, 本地域における製麻工場の分布とその変動について少し分 析を加えてみたい。

a ）原料との関係 A工場（明治20年創立）が本地域を指向したのは，本地域特産の野 州大麻の存在にある。この原料の存在こそは, この地に麻工業を吸引した最大の力であっ た。鹿沼はこの野州大麻取引の中心地であり，その集荷地であった。しかし，のちに大麻 が機械紡績に不向きであることから，野州大麻から北海道の亜麻，または中国の揚子江沿 岸で生産される苧麻へと原料の転換がなされた。

b ）動力との関係 A工場の第二工場が建設された時，種々の候補地から結局水力電気 との関係で日光の所野に決定されたといわれている。A工場でも行川および大谷川から， それぞれ $4 \mathrm{~km}, 16 \mathrm{~km}$ の用水路を開き, 工場背後の洪積期扇状地面との $11 \mathrm{~m}$ の落差を利用し 発電した。この地の地形が，この用水の引用に利用された。

c）工業用水との関係 ‘業用水には扇状地の地下水が利用せられたばかりでなく，黒 川の豊富な水もこのために利用されている。

d) 鉄道との関係 原料が地元から北海道，中国へと転換したことは述べた。すると， これら原料地との関係は当時はすべて鉄道を介して行なわれた。すなわち，鉄道の駅は即 原料地とみなすことができる。この原料の転換がなされた時点で製麻工場と原料地との関 係は，工場と鹿沼駅との関係に転換したことになる。そして，その後発生した工場は駅指 向型となった。

e ）東武線およびトラックとの関係 鹿沼市域内には東武日光線も走っているが，工場 が国鉄日光駅近接地を指向した理由には，私鉄線では輸送距離も短く，原料輸入の入口で ある港に接続していないためであったと思われる。また，トラック利用時代の到来ととも 
に，その後発生した工場は鹿沼駅近くの有力道路に沿って立地しはじめた。

\section{9. 福井県松岡町における織布業}

平林靖子（滋賀大）

地理学において地域研究を進めていくうえで, 地域の存立基盤をなしている土地とそこ に居住する人間との問題を考察していくこと，また他方において地域相互の関係を人間及 び物の移動に指標をおきその空間関係を考察することの二側面からの分析が必要であるこ とはいう.までもない。つまり地域を内からと, 外からとの二側面からアプローチしていく ことが，地域研究の重要な分析方法のひとつと考えられる。本研究では，織布業を成立せ しめた地理的条件や工業自体のもつ生産構造の問題などの織物産地自体の構造分析と, 織 布業の流通過程や労働力の需給関係などを指標とした他地域との関係という二側面からの アプローチを試みた。

対象地域である福井県松岡町は, 福井平野の東端に位置する人口約 1 万人, 面積 $18.61 \mathrm{~km}^{2}$ の小規模な町ではあるが，北陸織物産地の一翼を担い，明治時代以来，織物の町として存 立している。町の中央を九頭龍川が貫流し，景観的には農村地域的ではあるが，繊維工業 の事業所が219戸を数え,農業より工業の所得が卓越する。織物生産地域によく見られる農 家の自営製造業としての機業場はほとんど見られず，家族中心の企業とはいえ，そのほと んどが専業経営である。従って, 一般的にいわれる農村工業とはやや概念を異にしている といえる。機業場は市街地に集中し，地区によってはかなりの連担を示す。経営規模は， 織機台数 50 台以下が大半を占めているが, 一方 10 台以下の機業場は少なく, 織布業一般に いわれる零細性はやや弱い。労働力は, 町家, 農家の中・老年層の女子に依存し, その大 半が町内からであり，隣接の市町村から労働力を吸収するには至らない。一方，流通過程 においては，商社の系列化に組み込まれ，従属性を強いられている。

近年の深刻な不況下で繊維産業は危機的様相を強め, かつては一家専従, 長時間労働, 低顀金で不況の波を乗りきってきた松岡織布業も，体質改善の転換期に直面している。機 業の集約化，技術の高度化など織布業自体の質的変換が必要であろう。

発表では, 工場数・従業員数・規模別の構成・労働力の需給関係などの生産構造の実態 分析を中心に松岡織布業の構造を明らかにする。

\section{0.長野県長谷村における森林組合と労務状況}

中村恵子(明治大)

近年，林業生産が一般的に停滞しているなかで，森林組合は，林業生産事業体として地 域林業の中心的担い手として新たに注目されている。それは，林業労働に従事する労務班 の組織化を特徴としている。

本研究においては，長野県長谷村を事例として，山村地域において主要な産業である林 業を担う森林組合とその下に編成される労務班の実態を具体的・実証的に明らかにしよう と試みた。

長谷村森林組合は，林業構造改善事業導入を契機に1966年に村内 $2 つ の$ 組合の合併によ り設立された。組合事業の中心は造林で, 組合によって14班に編成された労務班のうち, 9 班は造林班であり, 他に山菜採取・その他 1 班, 伐出 2 班, 山菜加工 1 班, 民芸品生産 1 班からなっている。

このような班編成で71名が組織化された労務班員は, 自給程度の農業の他に日雇兼業に よって生活していた，山わば零細農家層に多い。また，製炭従事者がかなりみられ，長谷 村が製炭地帯であったことからして注目される。伐出については専門的技術を要するため, 在村の伐出専門の小業者や他県出身の林業労働者を中心として班を組んでいる。これらの 労務班員は，おもに公社・公団や地方公共団体の山林において従事しており，労務班員・ 
組合員の個別経営とも結びついたものになっていない。

労務班員の作業日誌や出勤台帳を分析してみると, 就労・就業状況については給料制の 班と請負制の班との間にいちじるしい差異が認められる。給料制労務班は規則的・規律的 であるが，請負制労務班は多くの班が不規則・無規律であり，班内の労務班員は出入りが 激しく，労務班員名簿では把握できなかった者が実際に就労していることもある。

また，過去数年間の離職者を調べると，離村した者もおり，大半の旧班員が林業とは関 連のない他産業部門へ移動していた。これは林業労働の不安定性をあらわしているともい えよう。

過疎化の進む浦地区の調査によると，森林組合は一定の就労の場を創出したものの，む しろ山林を売却してその離村資金にあてるという農・林家もあった。さらに現在も就労し ている労務班員も村をやがては離れようとしており，地域林家の個別経営や人々の生活の 安定ということなしには，今後も林業担い手の確保は困難になっていくと思われる。

\section{1。千葉港の変遷にみる港湾における公共性について 河名博子（法政大）}

千葉港は，かって共同の流通の拠点としてのみでなく, 漁民の生産の場であり, また住 民のリクリエーションの場であり，住宅地にも隣接し，生活の場でもあった。まさに生存 基盤としての公共性を有していたといえよう。こうした千葉港も，昭和30年頃になると， 公共港湾ということで，港湾の整備・増強に巨額な公共投資が注がれた。しかし，これま で多目的で公共水面として利用されていた千葉港は, 臨海部進出各企業の生産過程に直接 組み入れられ，生産に直結する流通の拠点としての機能のみとなってしまった。これによ って，工業資本は，高成長二高蓄積を遂げたのに対して，住民はその負担に苦しめられた ばかりでなく，漁業の壊滅，環境破壊，取扱貨物の激増による交通問題等の犠牲をしいら れたのである。

この産業港湾の優等生のようにいわれる千葉港も，40年後半になると，港湾運営方針の 転換を図る動きが見られるようになった。それは，さらに巨額の公共投資を投入して，港 湾における公共性を回復しようという動きである。だが，己れは地域住民との結びつき強 化のためと称しながら, 実は経済変動を迎えてより一層の公共投資に頼ろうとする民間資 本からの要請に答えたものなのである。住民は，港湾における公共性の回復で，さらに負 担を大きくしなければならないのに対して，今まで特別利潤を得てきた民間資本は，地元 住民に何ら福祉還元もないままにさらに蓄積を続けようとしているのである。

今後, 市民のための港湾づくりを目ざすというのであれば，現在，港湾においては市民 の意志と要望を吸収できるような体制になっていないことに注視しなければならないと考 える。とにかく，港湾の管理運営権は，地方自治体にあるとしながら，実際には国による 行財政面からの支配・指導が強いということを痛感した。そこで, 最後に, 港湾における 行政権限の地方分権による民主化，それを裹付ける財政的権限の確立が今後の課題である と指摘しておきたい。

\section{2. 相模湖における観光開発とその現況}

熊坂祐二（専修大）

都市化の進展と, それに伴なう人口の集中により生じた生活水の不足を解消するため, これまで全国各地において，多くのダムによる貯水池が建設されてきた。首都圏において は相模湖や奥多摩湖などが，その代表的なものとしてあげられるが，これらの人造湖は， 本来の目的の他に, 観光地としても発展してきた。人造湖を観光地としてみた場合, 他の 観光地には見られない数々の興味深い特色があると思われる。そこで筆者は, 人造湖にお ける観光開発とその実態を把握するため, 相模湖を対象地域として選定した。まず，その 
観光開発を段階的に見ていき，さらに現状について，奥多摩湖との比較も交えながら考察 を加え，また筆者が試みた観光実態調査の分析により，観光地相模湖の現況といったもの を明らかにしようとした。

相模湖における過去の観光客入込状況をみると, 昭和 22 年のダム完成以来年々伸び続け, 昭和48年には380万人台を記録したが,この年をピークとしてその後は減少の傾向にある。 また宿泊客数についてみると，昭和 43 年に大きく落ち込んでいるが，この最大の原因とし ては中央高速自動車道の開通があげられる。宿泊率を同じ人造湖である奥多摩湖と比較し た場合，奥多摩湖の方が高い值を示している。これは，両者の位置する地域の交通網の発 達程度と密接な関連を持っていて, 奥多摩湖の場合, 他地域への移動の困難なことが宿泊 施設を発達させ，宿泊率を高いものにしていると思われる。このように，モータリゼーシ ヨンの進展と交通網の発達は，相模湖観光に量的な面ではプラスに働いたものの，質的な 面でマイナスに働き，宿泊者数，あるいは観光消費を減少させていった。現在，相模湖は 日帰り主体の，それも土曜，日曜に集中する家族慰安やドライブの休噭地として利用され る傾向が強く，そのことはアンケート調査によっても確かめることができた。

以上述べたように，相模湖では，車社会の発達により宿泊業が危機に立たされていて， これからは，いかに行動範囲の拡がった観光客を立ち寄らせるか，ということが重要にな つてくる。それには魅力的な観光資源が必要になってくるが，これから開発するにしても 飲料用の水源地であるための規制により，かなりの困難が予想される。しかし，現在のま までは観光地としての発展は望めず，これらの問題をどのように克服していくかが今後の 相模湖の課題となっている。

\section{3.函館市の商店街の性格}

杉本 真 (茨城大)

函館市の本町・五梭郭商店街は人口急増地域をバックボーンとして，近年急激に商業の 集積と近代化を果たし，副都心的性格を持つに至っている。そこで，この副都心商店街の 機能的構造や将来動向について考察を試みた。

1. 函館市の人口の推移 国勢調查の結果によると, 昭和 35 年〜 40 年, 40 年〜 45 年, 45 年 50 年の 3 期間において，函館駅前・大門商店街（中心商店街）を中心とした地区では， 一貫して $10 \%$ 以上の減少を続け，本町・五棱郭商店街の後背地である東部地域は逆に $10 \%$ 以上の増加を示し，函館市の人口重心は東部地域に大きく傾斜している。

2. 買物動向調査からみた商店街の性格この調查はアンケート形式により, 函館市内 の小学校之高等学校に合計845枚を配布し，636枚を回収した(回収率75.3\%)。この調査結 果から次のようなことが判明した。

函館駅前・大門商店街は他の商店街に比べて最寄り品の買物が少なく $(6.0 \%)$, 買伵り 品・専門品が圧倒的に多くなっており，函館の中心商店街としての機能を十分果している ものと考えられる。本町・五棱郭商店街も買廻り品・専門品のウエイトが高く買物全体の

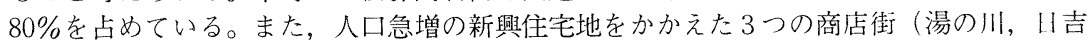
・花園町, 赤川通り商店街) は, ともに最寄り品の買物が70\%以上もあり, 日用品購型型 商店街の性格が強い, ということができる。

3. 本町・五棱郭商店街の将来動向 買物動向調查の結果によると, 本町・五梭郭商店 街の買物傾向は副都心的商店街としての構造を有しているものと考えられる。そこで都心 機能の集積度と販売効率を，函館駅前・大誾店街との比較において検討してみた。

都心機能では, 特に社交娛楽機能について, 函館駅前・大門商店街が1,366対344(単位： 軒, 職業別電話帳函館市版 昭和52年 4 月現在）と圧倒的に優位である。しかしながら, 販壳効率の一指標としての売上高伸び率（昭和41年〜 49年）は，函館駅前・大門商店街が 
市平均を下回っているのに比べ，本町・五稜郭商店街は市平均の 3 倍にもなっている。

したがって，都心機能諸施設の集積において質・量とも，函館駅前・大門商店街が優っ ているが，売上高で高い伸び率を示す本町・五稜郭商店街は消費機能の向上に今後大きな 期待がもてる，ということができる。

\section{4．宇都宮市の小売商圈}

武田義正（宇都宮大）

都市圈に関する調査は, 数多くの研究がなされているが, この研究は, 栃木県の政治. 経済・文化の中心地である宇都宮市の小売商圏について，その範囲を考察したものである。

調査方法は周辺法によるものとし，杤木県内の一部の地区を除いた全県を調査地域とし た旧市町村 1 中学校の学区を単位地域とし，アンケート調査票を各学校に委託して, 計114 校に，総数10,250枚を配布した。

宇都宮市の小売商圏は，かなり広い地域におよび，東北本線沿いの北部に拡がっている。 これは，すべての交通網体系が宇都宮市を中心に発着しているためである。

品目別にみると，低級買廻品においては，宇都宮市の絶対優勢を示す地域はわずか宇都 宮市に隣接する市町村だけに限られてしまうが，高級買廻品においては，著しく拡大し， とくに，北方にのびているのが特徵である。全体的にみると，北にのびたたまご型をして いる。しかし，南部に宇都宮市の小売商圈が拡がっていないのは，両毛線沿いに小山・栃 木・佐野・足利といった独自の小売商圈をもつ中小都市が列状に存在するためであり，こ の方向では宇都宮市の小売商圈は著しく後退している。

次に最近大型店（ここでは売場面積 $1,500 \mathrm{~m}^{2}$ 以上)の進出が注目されているが，宇都宮市 の大型店の勢力圈を調査した。それによると，大型店の商圏は，高級買廻品の商圏よりも 広い範囲にわたっている。これは，大型店は高級・低級の別なく両方の性格を持ち得てい るからではないかと思われる。しかし，ここでも南方へは拡がらず，大型店においても， それぞれ独自な絶対地域が南部には存在していることがわかる。

以上のように，宇都宮市の小売商圈は，かなり広い地域にわたり存在し，経済的にも， 杤木県の中心地であることがわかる。

\section{5。通勤者の鉄道利用から見た都市の類型}

小林幹政（静岡大）

都市の分類法としては，文化面・政治面・産業面など，種々の見地からの分類法がある が，私は，入通勤者の鉄道利用形態からの分類を施してみようと考えた。調査に使った材 料はすべて, 昭和 45 年度国勢調査報告が基となっており，その中の数值を吟味して，図 · 数表を作製した。ただし，大都市圈は省き，地方の人口 10 万人以上の都市を対象とした。 最初に，中心都市の総人口と入通勤者の鉄道利用率との相関を見てみたが，ほとんど相関 は見られなかった。次に，鉄道距離（通勤距離）と鉄道利用率との相関をとってみたが, これは種々の結果からみて, 比例関係にあると考えられた。ただし，極めて近距離の場合 は，必ずしも比例関係が成り立たず，その境い目の距離，すなわち，それ以上になると急 に鉄道利用率が高くなる距離を考えてみると，主に距離と利用率との相関表から，15kmと いう值が考えられた。さらに，中心より $15 \mathrm{~km}$ 以遠で鉄道沿線にある通勤人口を人通勤者の 人口総計で割った值を「 $15 \mathrm{~km}$ 以遠の鉄道沿線人口比」と名付け，これと鉄道利用率との相 関をとってみた。ここから都市分類ができると思ったからである。この二つは，ほぼ比例 していることがわかった。一方，中心市の市域（面積）が広ければ，鉄道沿線人口比も高 くなることに気づいたので，市域の広さは，そのまま通勤圈の広さということができると 考えた。これまでの経過から都市をタイプ分けしてみると次のようになる。

(1)通勤圈（市域）が広大なため，鉄道利用率が高い都市郡……苫小牧・青森・秋田・下 
関など。

(2)同じく狭いため，利用率の低い都市群……倉敷・広島・都城など。

(3) 1 - 2 の中間の性格を持つもの（市域が広くも狭くもなく，鉄道利用率も高くも低く もないもの。特例として鉄道利用率が低くても市域が広いもの（山口）, 利用率が高くても 市域の狭いもの（特に弘前）がある。

また，(2)の中で，純粋に市域の狭いことだけからくる利用率の低さ（広島では昭和45年 の国勢調査以後, 中心上り $15 \mathrm{~km}$ 以内で多くの人口を送り込んでいる町の吸収合併を行なっ たので，現在では鉄道利用率は大幅に高くなっている）が，その都市の性格となっている とこううもあれば，鉄道敷設距離の短さからくる利用率の低さ，他の交通機関に比して鉄道 の整備のたち遅れからくる利用率の低さなど, はっきりと分類しにくい面も多く残ってい る。

\section{6. 大都市近郊の住宅地域一門真市における特性——岡部泰廣（立命館大）}

[目的〕大都市近郊の住宅地化の傾向には，市街地に連担するものと集団住宅地のよ うに飛地的に進展するものとがある。門真市の北部地区は前者の典型であるが，南部地区 には後者の例である門真団地が存在する。そこでこの門真市を例に, 前者(市街地連担型) の後者(集団住宅地型)に対する対照的な特色を探りたい。

[方法]まず門真市の住宅地域としての特性を把握するために, 統計資料などから京 阪沿線 4 市の中での位置づけを行ない，次に市内の住宅地化の地域的展開を概観した。さ らに微視的に住宅地を類型化する試みとして，門真団地の 2 町を含む典型的な 5 町を選定 して町ごとに家屋分類を行なった。そして聴き取り調査から各町の性格と住宅地域形成の 特色を探り，北部地区と南部の門真団地とを比較した。

〔結果〕門真市は京阪沿線 4 市の中では住宅地化が遅れていたが，昭和35年から45年 にかけて急速に進展した。しかし，住宅は狭小・過密であり，民営借家率は6 割にも達し， 土地条件も悪い。昭和 45 年以降は北部の人口減と南部の人口増が均衡して市の人口は停滞 している。北部の各町の人口はほとんどが増加から減少に転じているが，人口減少開始時 期で分類すると，大阪市への所要時間が短く，早くから住宅地化した地区ほどその時期は 早い。

家屋分類により類型化された町

北部地区 $\begin{cases}\text { 幸福町 } & \text { （商住混在地区） } \\ \text { 上野口町（小規模一戸建住宅卓越地区） }\end{cases}$

門真団地 $\left\{\begin{array}{l}\text { 千石西町（中層アパート卓越地区） } \\ \text { 千石東町（一戸建住宅卓越地区） }\end{array}\right.$

石原町は人口密度が551.5人/haという超過密地区であるが，その原因は短期間に急激に建 築された文化住宅の過密さにあった。一戸建住宅は北部地区では敷地面積 $100 \mathrm{~m}^{2} に$ 満たない 小規模なものが多いが，千石東町の分譲地では $200 \mathrm{~m}^{2}$ ほどで，両者の格差が指摘できる。

以上のように門真市の市街地連担型の住宅地化は，開発主体が中小の民間資本であるた め，土地条件や住環境の検討も不十分で，しかも狭小・過密な住宅建設が行われており， 急増してきた人口が逆に減少する傾向にある。

\section{7．宇都宮市における高層建築物について}

山本光信（宇都宮大）

宇都宮市の市街地には，4階から13階のビルが建っているが, 周辺部のビルは $4 \sim 5$ 階 までで, その分布の密度も極めて低い。ビル立地の外縁への拡大は, 大谷街道・東京街道 